\title{
Employers' Perception Of Attributes Of Teachers And Training Practices In Pakistan: Difference Between Demand And Supply
}

Muhammad Sarwar, University of Worcester, UK Naeemullah Khan, Punjab, Pakistan

Riffat Awan, University of Sargodha, Pakistan

Muhammad Bashir, University of Worcester, UK

\begin{abstract}
The purpose of this paper is to identify the qualities employers look for in a teacher candidate. The objectives of the study were to compare the employers' perception of personal qualities, personal habits, personal skills/abilities and teaching skills of teachers, desired by the market and the actual attributes of teachers trained by training institutions. All private schools of the Province Punjab were the population of the study. Three districts of the Punjab province were selected as target population to collect data. Thirty schools from each district were selected as a sample. It was concluded that the difference between desired and possessed qualities is quite significant. It was felt that a strong coordination between training institutions and schools is badly needed to transform training programs to make them compatible with the market demands.
\end{abstract}

Keywords: Employers' Perception, desired attributes, actual attributes, Market, Training institutions, Pakistan

\section{INTRODUCTION}

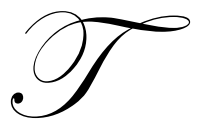

he quality of education in an educational institution depends upon the quality of teacher, which in turn depends on the quality of teacher education (Khan, 2005). The standard of education can be improved by preparing competent and effective teachers (Bhat and Ganihar, 2006). Collaboration and cooperation between schools and universities are major elements in successful programs that have brought real change to teacher education (Russell McPherson, 2001). In Pakistan the employers (in private schools are not satisfied with the quality of prevalent teacher training. Employers feel that there is little difference in the performance of trained and untrained teachers in Pakistan. So, it is needed to adapt teacher training to the carefully assessed needs of the market. Need assessment involves a systematic study of the problems in order to make effective decisions or recommendations about what should happen next. Needs assessment is conducted to determine the best method of addressing a problem or opportunity to satisfy the consumers. Teacher training must consider market mechanisms to improve the programs and be responsive to consumers (Finkelstein \& Grubb 2000). The role of the teacher is changing so fast that no teacher training can probably cope with the fast changing expectations of the society (Sing, 2005). The quality of most of the pre-service training for most of the teacher training institutions is outmoded and low as compared to international standards (Qureshi, 2000). In Pakistan most teacher training institutions are after methodologies and contents are being neglected. There is no emphasis on content-cum-methodology of teaching the different school subjects (Sharma, 1992).

In Pakistan the private sector employers are not satisfied with the performance of young trained teachers's they lack the personal and professional qualities which the employers are seeking for. Literature review revealed that few studies have been carried out in Pakistan about market based teacher training. There is a need to discover what 
the different qualities of teachers are which employers seek for in their employees as teachers. The teacher training institutions and prospective teachers may then be better able to tune themselves with the needs of the market. The present study was designed to investigate the qualities of teachers which are desired by the employers in Punjab Province of Pakistan. The study was further delimited to cities of Gujranwala, Hafizabad and Sargodha.

The main objective of the study was to compare the perception of employers for the personal qualities, personal habits, personal skills/abilities and teaching skills of teachers, desired by the market and trained by training institutions

\section{HYPOTHESES OF THE STUDY}

The following were the hypotheses of the study:

1. There is no difference in the employers' perception of personal qualities of teachers desired by the market and their perception of personal qualities that trained teachers actually possess.

2. There is no difference in the employers' perception of personal habits of teachers desired by the market and their perception of personal qualities that trained teachers actually possess.

3. There is no difference in the employers' perception of skills/abilities of teachers desired by the market and their perception of personal qualities that trained teachers actually possess.

\section{METHODS}

All the private registered schools of the Punjab province were the population of the study. Private schools of three districts (Gujranwala, Hafizabad and Sargodha) were randomly selected from the 34 districts of the Punjab. From each district 30 registered private schools were selected conveniently so 90 principals of these schools were the total sample of the study.

For the survey of employers perceived needs, a questionnaire was developed after interviewing sixteen of them. There were 36 statements / questions attended by a five point Likert scale. The instrument was pilot tested to establish its validity and reliability. The Cronbach reliability coefficient was .89 . For data collection the researchers personally briefed the respondents about the questionnaires and the purpose of the study. After collection of data the mean of all the items were calculated. The hypotheses were tested using paired sample two tailed t-test. The means of desired attributes and perceived possessed qualities were compared for statistically significant difference. Moreover, the means were ranked in descending order.

\section{RESULTS}

$\mathbf{H}_{\mathbf{0 1}}$ "There is no difference in the employers' perception personal qualities of teachers desired by the market and trained by training institutions"

Table 1: Means, SD and t-test of desired and possessed Personal Qualities of teachers

\begin{tabular}{|c|c|c|c|c|c|c|c|}
\hline Variable & Mean & N & Std. Deviation & Std. Error Mean & T & df & $\begin{array}{c}\text { Sig. } \\
(\mathbf{2} \text {-tailed) }\end{array}$ \\
\hline qualities desired by the market & 13.4667 & 90 & 1.60896 & .16960 & \multirow{2}{*}{9.192} & 89 & \multirow{2}{*}{.000} \\
\cline { 1 - 5 } qualities training institutions & 10.6889 & 90 & 2.40152 & .25314 & & \\
\hline
\end{tabular}

Table 1 shows the paired samples t-test value is 9.19 which is significant at .05 level. It was found that a significant difference exists between means of employer's perceptions of personal qualities desired by the market and trained by the training institutions.

$\mathbf{H}_{\mathbf{0 2}}$ "There is no difference in the employers' perception personal skills/abilities of teachers desired by the market and trained by training" 
Table 2: Means, SD and t-test of desired and possessed Personal skills/abilities of teachers

\begin{tabular}{|c|c|c|c|c|c|c|c|}
\hline Variable & Mean & $\mathbf{N}$ & $\begin{array}{c}\text { Std. } \\
\text { Deviation }\end{array}$ & $\begin{array}{l}\text { Std. Error } \\
\text { Mean }\end{array}$ & $\mathbf{T}$ & df & $\begin{array}{c}\text { Sig. } \\
\text { (2-tailed) }\end{array}$ \\
\hline $\begin{array}{l}\text { Personal skills/Abilities desired } \\
\text { by the market }\end{array}$ & 22.10 & 90 & 2.50 & .26 & \multirow{2}{*}{10.05} & \multirow{2}{*}{89} & \multirow{2}{*}{.000} \\
\hline $\begin{array}{l}\text { Personal skills/Abilities trained } \\
\text { by training institutions }\end{array}$ & 17.79 & 90 & 3.38 & 6.3 & & & \\
\hline
\end{tabular}

The above table shows the paired samples t-test value is 10.05 which is significant at .000 levels which is less than .05 levels. Hence the null hypothesis has been rejected. Therefore there is a significant difference between means of employers' perceptions of personal skills/abilities desired by the market and trained by the training institutions.

$\mathbf{H}_{\mathbf{0 3}}$ “There is no difference in the employers' perception of personal habits of teachers desired by the market and trained by training institutions"

Table 3: Means, SD and t-test of desired and possessed Personal Habits of teachers

\begin{tabular}{|c|c|c|c|c|c|c|c|}
\hline Variable & Mean & $\mathbf{N}$ & $\begin{array}{l}\text { Std. } \\
\text { Deviation }\end{array}$ & $\begin{array}{l}\text { Std. Error } \\
\text { Mean }\end{array}$ & $\mathbf{T}$ & df & $\begin{array}{c}\text { Sig. } \\
\text { (2-tailed) }\end{array}$ \\
\hline $\begin{array}{l}\text { Personal Habits desired by the } \\
\text { market }\end{array}$ & 13.4667 & 90 & 1.60896 & .16960 & \multirow{2}{*}{9.19} & \multirow{2}{*}{89} & \multirow{2}{*}{.000} \\
\hline $\begin{array}{l}\text { Personal Habits trained by } \\
\text { training institutions }\end{array}$ & 10.6889 & 90 & 2.40152 & .25314 & & & \\
\hline
\end{tabular}

Table 3 shows the t-test value is 9.19 which is significant at .05 level. It is therefore, concluded that there is a significant difference between means of employer's perceptions of personal habits desired by the market and trained by the training institutions.

$\mathbf{H}_{\mathbf{0 4}}$ "There is no difference in the employers' perception of teaching skills of teachers desired by the market and trained by training"

Table 4: Means, SD and t-test of desired and possessed Teaching Skills of teachers

\begin{tabular}{|c|c|c|c|c|c|c|c|}
\hline Variable & Mean & $\mathbf{N}$ & $\begin{array}{c}\text { Std. } \\
\text { Deviation }\end{array}$ & $\begin{array}{l}\text { Std. Error } \\
\text { Mean }\end{array}$ & $\mathbf{T}$ & Df & $\begin{array}{c}\text { Sig. } \\
\text { (2-tailed) }\end{array}$ \\
\hline $\begin{array}{l}\text { Teaching skills desired by the } \\
\text { market }\end{array}$ & 29.5222 & 90 & 3.81666 & .40231 & \multirow{2}{*}{8.87} & \multirow{2}{*}{89} & \multirow{2}{*}{.000} \\
\hline $\begin{array}{l}\text { Teaching skills trained by } \\
\text { training institutions }\end{array}$ & 23.6444 & 90 & 5.05767 & .53313 & & & \\
\hline
\end{tabular}

Table 4 shows the paired samples t-test value is 8.87 which is significant at .000 levels which is less than .05 levels. Hence the null hypothesis has been rejected. Therefore there is a significant difference between means of employer's perceptions of teaching skills desired by the market and trained by the training institutions.

\section{DISCUSSION AND CONCLUSIONS}

The employers' perception of qualities possessed by trained working teachers in the private sector was the main focus of this research. It was concluded that employers' perceptions of personal qualities desired by the market and those possessed by the trained teachers are significantly different on all grouped categories. It means that the teacher training institutions are not producing the attributes that employers perceive as being important on personal qualities. There is a statistically significant difference between personal skills/abilities desired by the market and trained by the training institutions. The employers expected much better personal habits than they judged the trained teachers actually had. 
Employers are not satisfied with the teaching skills of trained teachers. There is a significant difference between means of employers' perceptions of teaching skills desired by the market and trained by the training institutions. These shows that possibly the employers are considering only a few aspects of an effective teacher. The findings of the study may be interpreted with caution as the employers are only one of the many stake holders of educations so their perceptions should be given appropriate weightage.

The curriculum in teacher training courses must be revised to impart proper teaching methods, not the current emphasis in classrooms of more time, more subjects and more courses

\section{EDUCATIONAL IMPLICATIONS}

A liaison between teacher training institutions and the schools is necessary for improving teacher training. In many developed countries the universities and schools are linked together and take the benefit of experiences of each other to make the teacher training more market oriented. So, our teacher training institutions needs to know the market mechanism to meet the challenges of rapidly changing world of knowledge and to tune themselves to the demands and requirements of the market. The private sector in education is expanding in Pakistan both in quality and quantity. If the training institutions transform themselves according to the needs of job market and their end product can find placement there quite easily.

\section{AUTHOR INFORMATION}

Sarwar, Muhammad presently working as post-doctoral fellow in the Institute of Education, University of Worcester, UK is Assistant Professor in Department of Education, University of Sargodha, Pakistan. He did his M.Phil. in Education from Allama Iqbal Open University, Pakistan and Ph.D. in Education from University Institute of Education and Research, UAAR, Pakistan. E-mail: m.sarwar@worc.ac.uk

Khan, Naeemullah is working as Senior Headmaster in Department of Education, Punjab, Pakistan; He did his Ph.D. in Education from University Institute of Education and Research, UAAR, Pakistan.

E-mail: drnaeemullah2003@yahoo.com

Awan, Riffat is working as Assistant Professor in Department of Education, University of Sargodha, Pakistan. She did Ph.D. in Education from University Institute of Education and Research, University of the Punjab, Pakistan. Email: riffarukh@yahoo.com

Bashir, Muhammad presently working as post Doctoral fellow is controller of Examinations, University of Sargodha, Pakistan. He did his Ph.D. in Education from University Institute of Education and Research, UAAR, Pakistan E-mail: m.bashir@worc.ac.uk

\section{REFERENCES}

1. Bhar, K.V and Ganihar N.N.(2006) . Total quality culture in teacher education colleges, New Delhi: Mahaveer \& sons

2. Career and Services. (2004). What New Educators Need to Know about Teacher Qualities. .Teacher Qualities. Data Retrieved on October 7, 2007 from https://uwec.edu/career/students/jobsearch/teachers/teacherqualities.htm

3. Finkelstein, N.D. and W. N. Grubb (2000). Making Sense of Education and Training Markets: Lessons from England American Educational Research Journal, Vol. 37, No. 3, PP. 601-631

4. How to raise the number of qualified teachers in Pakistan(2004)retrieved on May 24, 2009 from http://www.yespakistan.com/education/qualified teacher.asp

5. Qureshi, M.A.(2000). Towards Education. Lahore: Dogar Publications

6. Robertson, H. (2003). Toward a Theory of Negativity: Teacher Education and Information and Communications Technology Journal of Teacher Education 54; 280

7. Russell, T and McPherson, S (2001).Indicators Of Success In Teacher Education. Quebec City .Laval University 
8. $\quad$ Sharrma, S.R. (1992). Teacher Education in India. New Delhi: Anmol Publications

9. Sheikh, M.A.(2000). Teacher Education in Pakistan. Study guide CC.829. Islamabad: Allama Iqbal Open University

10. Singh, Y.K.(2005).Teacher Education. New Delhi: A.P.H. Publishing Corporation

11. The University of Albama Birmingham School of Education, (ND). Conceptual Framework and Assessment Model, UAB School of Education, the University of Alabama at Birmingham. Data Retrieved on September 9, 2007 from http://www.ed.uab.edu/soe/professionalcommitments.htm 
NOTES 